\title{
Sociologia e literatura
}

A renovação da crítica na Argentina

Alejandro Blanco

Tradução de Luiz Carlos Jackson
Originariamente publicado como introdução a uma coletânea de textos sobre os grupos literários de Boedo y Florida (1964), e incluído mais tarde, com ligeiras modificações, no excelente Estudios de literatura argentina (1969), o texto de Adolfo Prieto inaugurou uma nova perspectiva de análise sobre a irrupção das vanguardas que a crítica posterior aprofundou". "Boedo e Florida” constitui ainda uma introdução excelente a uma obra e a um estilo de trabalho que articula crítica e sociologia da literatura de forma tão nuança$\mathrm{da}$ a ponto de desfazer as fronteiras tradicionais entre essas abordagens.

Segundo Prieto, o surgimento das vanguardas na década de 1920 resultou do adensamento da vida intelectual na Argentina, iniciado no final do século XIX, momento em que a literatura como atividade socialmente organizada se impôs como o eixo da vida cultural nesse país. O ensaio examina os fatores históricos mais gerais que condicionaram esse processo, esboça uma sociologia dos grupos intelectuais protagonistas, calibra as diferentes apostas estéticas e avalia o significado da experiência no contexto da história da literatura argentina.

Filho de imigrantes espanhóis, Adolfo Prieto nasceu em 1928 na província de San Juan e se formou na Faculdade de Filosofia e Letras da Universidade de Buenos Aires. Sua longa trajetória inclui uma das obras mais originais da crítica e da história da literatura argentina, e uma destacada atuação como professor e pesquisador. Ensinou nas universidades de Cór-
1. Ver, principalmente, Carlos Altamirano e Beatriz Sarlo, Ensayos argentinos: de Sarmiento a la vanguardia. Buenos Aires, CEAL, 1983. 
2. Expressão cunhada pelo crítico uruguaio Emir Rodríguez Monegal (El juicio de los parricidas, 1956), em função da posição assumida por essa geração diante das figuras então dominantes na vida literária argentina, como as de Jorge Luis Borges, Eduardo Mallea e Ezequiel Martínez Estrada.

3. A segunda edição, ampliada e com algumas modificações, foi publicada pela mesma editora, em cinco volumes, no início da década de 1980, sob a direção de Suzana Zanetti. doba, Cuyo e do Litoral, tornando-se (no início dos anos de 1960), nesta última, diretor da Faculdade de Filosofia e Ciências do Homem, do Instituto de Letras e do Boletín de Literaturas Hispánicas. Nas décadas seguintes, lecionou em várias universidades norte-americanas.

Adolfo Prieto foi um dos principais integrantes da geração dos anos de 1950, também conhecida como "geração dos parricidas" ${ }^{2}$, reunida inicialmente em torno do Centro de Estudantes da Faculdade de Filosofia e Letras da Universidade de Buenos Aires. Duas revistas, Centro (1951-1959) e Contorno (1953-1959), formaram a plataforma de lançamento e o laboratório das inquietudes e dos projetos intelectuais dessa nova geração. Ao lado dos irmãos Ismael e David Viñas, Noé Jitrik, Adelaida Gigli, Regina Gibaja, Juan José Sebreli, Oscar Masotta, entre outros, foi uma das figuras mais expressivas do movimento intelectual que afastou a análise do fato literário dos moldes tradicionais conformados pela estilística e pela filologia, interrogando-o por meio dos vínculos estabelecidos com a sociedade e com a política.

No interior de sua geração, Prieto foi, sem dúvida, o crítico mais afinado com a sociologia, e seu projeto de realizar uma história social da literatura é indissociável do processo de modernização intelectual e disciplinar promovido desde meados dos anos de 1950 pelas ciências sociais emergentes e, sobretudo, pela sociologia. Em 1956, o autor publicou Sociología del público argentino, uma abordagem inédita na tradição da crítica e da história literária argentinas, focada no circuito social da literatura (autor-obra-público). Nesse livro, definiu o enquadramento básico de seu projeto intelectual, que encarou sempre o fenômeno literário como um sistema vivo de relaçōes. Proyección del rosismo en la literatura argentina (1959), La literatura autobiográfica argentina (1962) e El discurso criollista en la formación de la Argentina moderna (1988) foram as obras modelares dessa orientação geral. Ainda que de maneira indireta, esse projeto também pode ser reconhecido numa obra coletiva que supervisionou, Capitulo de la historia de la literatura argentina (1967-1968), publicada pelo Centro Editor de América Latina em 59 fascículos semanais, cada um deles acompanhado por um livro de bolso (quase sempre uma seleção de textos), o último destes o Diccionario básico de la literatura argentina (1968), redigido pelo próprio Prieto ${ }^{3}$. Pensada para um público amplo de leitores não especializados, a terceira das principais histórias da literatura argentina (a primeira foi realizada por Ricardo Rojas entre 1917 e 1922; Rafael Arrieta dirigiu a segunda entre 1958 e 1960) acabou convertendo-se em ponto de referência obrigatório e 
fonte de muitas hipóteses que orientaram a crítica e a história da literatura subsequentes.

Apesar de breves, os dados apresentados sugerem um notável paralelismo com o que ocorreu na Universidade de São Paulo, quase ao mesmo tempo. Nos dois casos, com efeito, a renovação da crítica literária - encabeçada no Brasil por Antonio Candido e na Argentina por Adolfo Prieto - acompanhou o desenvolvimento sem precedentes da sociologia nos mesmos anos, liderado por Florestan Fernandes e Gino Germani, respectivamente. Verdadeiro jogo especular, define um momento em que as duas disciplinas caminharam lado a lado, envolvendo um complexo sistema de disputas e trocas a ser revisto.

Alejandro Blanco é professor de sociologia e membro do Programa de História Intelectual da Universidade Nacional de Quilmes. É autor de Razón y modernidad. Gino Germani y la sociología en la Argentina (Buenos Aires, Siglo XXI, 2006). E-mail: ablanco@unq.edu.ar. 